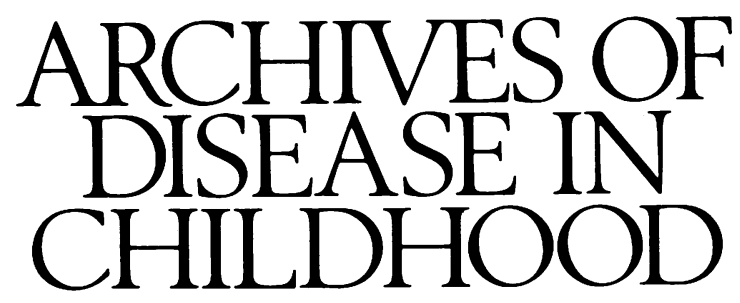

The Fournal of the British Paediatric Association

\title{
Annotations
}

\section{Cough - but is it asthma?}

The consensus statement defines asthma as 'recurrent wheeze and/or cough in a setting where asthma is likely $\ldots$. Doctors used to be very ready to ascribe cough in children to bronchitis, ${ }^{2}$ but now there is some anxiety that too many children who cough recurrently are being diagnosed asthmatic and treated inappropriately. ${ }^{3}$ Is recurrent cough a marker for wheeze and is it justifiable to treat it with asthma medication?

\section{Cough and bronchoconstriction}

The relationship between cough and wheeze has received recent attention. ${ }^{45}$ Cough receptors are sited both in the mucosa and smooth muscle of the airways. It has been proposed that viruses and other agents associated with wheezing illnesses strip away mucosal epithelium to expose subepithelial cough receptors ${ }^{6}$ thereby increasing the sensitivity of the cough reflex. Patients with acute viral infections have an increased cough sensitivity to agents such as citric acid and this returns to normal when the patient has recovered. ${ }^{7}$ Increased amounts of locally active mediators also increase cough sensitivity ${ }^{8}$ and this might explain why asthmatics cough. In adults whose asthma is controlled there is no such increase in sensitivity. ${ }^{9}$ Neither bronchoconstriction caused by inhalation of methacholine nor bronchodilatation by $\beta$ agonists alters cough receptor sensitivity in either normal or asthmatic subjects. ${ }^{10-12}$ It appears then that there is neither a fundamental increase in cough receptor sensitivity in asthma nor do changes in bronchomotor tone alter cough sensitivity.

Voluntary coughing is a well described cause of wheezing in asthmatics ${ }^{13}$ possibly by similar mechanisms to exercise. Histamine and methacholine produce both cough and bronchoconstriction and while these are closely related ${ }^{14}$ the evidence suggests that they can be triggered independently. Sodium cromoglycate blocks the bronchoconstriction caused by water ${ }^{15}$ but not the cough, while lignocaine blocks the cough but not bronchoconstriction. Cough appears to be related to respiratory water loss after exercise, ${ }^{16}$ while bronchoconstriction is more related to respiratory heat loss. ${ }^{17}$ These observations suggest that in asthma the mechanisms of cough and wheeze are related but can be independently triggered.

Obviously there is a lot more to understand about the cough that accompanies wheezing. Current evidence suggests that during a wheezy episode, cough is not related to airway calibre and is more likely to be related to airway inflammation, mucous in the airways, and direct sensitivity to triggers.

\section{Clinical and epidemiological considerations}

A group of children with chronic cough were studied by means of methacholine challenge to discover whether cough or bronchial hyper-responsiveness predicted the development of asthma. ${ }^{18}$ Half had significant bronchial hyper-responsiveness. However, only $11 \%$ on follow up turned out to have asthma, half of whom had negative methacholine studies at the time of the cough.

Further epidemiological evidence supports the observation that recurrent cough is a poor marker for wheeze. In one study, only half of a large group of children who coughed also wheezed. ${ }^{19}$ Recurrent cough affected about $20 \%$ of 7 year olds and $9 \%$ of 11 year olds, a difference probably reflecting the incidence of respiratory infection in the two age groups. There was no difference in the prevalence of wheeze, $12 \%$ in both groups. Children with cough without wheeze had bronchial hyper-responsiveness but were no more atopic when compared with children with no respiratory symptoms. ${ }^{20}$ In another study of 3187 children aged 7 and 8 years cough was reported in $22 \%$ and wheeze in $15 \% .{ }^{21}$ Thirteen per cent coughed without wheezing. Of those who coughed about a third were atopic and one third of these had bronchial hyper-responsiveness in response to methacholine challenge. Of those with cough and no wheeze and who were not atopic, $8 \%$ were positive to challenge testing. Thus cough is a poor predictor of wheeze and atopic status.

Furthermore, testing for bronchial hyper-responsiveness using an agent such as methacholine will not help to clarify whether the child with chronic cough has asthma or will develop asthma as it is neither sensitive nor specific for asthma. While it is true that most patients with moderate and severe atopic asthma have very reactive airways, in a study in New Zealand, only $50 \%$ of children with mild asthma were shown to have reactive airways. ${ }^{22} \mathrm{~A}$ total of $26 \%$ of children with cough and no wheeze and $8 \%$ of children with no symptoms at all were reactive. The variability of bronchial hyper-responsiveness over time in children with respiratory symptoms is well known. ${ }^{23}$

Bronchoconstriction or overt wheeze in response to exercise testing would be strongly suggestive that a chronic cough is indeed a reflection of asthma. Substantial bronchoconstriction is seldom found in non-asthmatic 
subjects $^{24}$ but at least $20 \%$ of asthmatics do not have exercise induced wheezing.

\section{Cough and treatment with asthma medication}

Whether a child with chronic cough, no history of wheeze, and no wheeze on exercise will respond to medication cannot be predicted by any testing.

Cough variant asthma is considered by some to be an entity. Fifteen children who presented with cough and no wheeze demonstrated changes after exercise in pulmonary function similar to children with asthma and all responded to bronchodilators. ${ }^{25}$ About $5-6 \%$ of children with asthma are said to present with cough ${ }^{26}$ but most of these patients demonstrate abnormal pulmonary function studies consistent with asthma. Some do not, and a diagnosis of asthma is made simply on the evidence of response to treatment with bronchodilators.

The value of terbutaline in a controlled trial in a group of adults with chronic 'allergic' cough has been demonstrated ${ }^{27}$ but there is little information about the efficacy of $\beta$ agonists as antitussives - as distinct from bronchodilators - in children. It is very important not to extrapolate the results of drug trials in adults with cough to children, as children are far more likely to have non-specific cough after respiratory tract infections. In a very small study, no benefit from $\beta$ agonists in children with chronic cough was found. ${ }^{28}$ In another small study of children with asthma using voice activated tapes to record coughing, night time cough persisted in spite of the use of asthma medication. ${ }^{29}$ To date there are no good randomised placebo controlled trials in children that demonstrate the value of $\beta$ agonists as antitussives and certainly no trials that demonstrate the value of corticosteroids. A group of adults with chronic cough treated with inhaled steroids did not benefit. ${ }^{30}$

$\beta$ Agonists are sometimes used for a trial period in children with a long history of troublesome cough without documented wheeze. Of course it is possible that cough may be the only complaint because the child and his parents are unaware of wheeze. ${ }^{31}$ If the benefit of $\beta$ agonists is to be evaluated in this way, then symptoms and peak expiratory flow rates should be recorded with and without treatment. Improvement on medication could be purely coincidental and represent the resolution of a respiratory infection. Should the cough return when $\beta$ agonists are discontinued, then treatment with these drugs seems reasonable, at least for a short period. Without further evidence to support a diagnosis of asthma it is unreasonable to prescribe corticosteroids. Much more work needs to be done in evaluating the effect of asthma treatment on cough as well as wheeze. ${ }^{4}$

Thus, children presenting with chronic cough and no wheeze may or may not have associated airways narrowing. A diagnosis of asthma should not be given until evidence of airways lability has been demonstrated. This should avoid the inappropriate treatment of cough with drugs such as inhaled steroids. 'Doctor diagnosed' asthma is a term sometimes used by epidemiologists. If the epidemiology of asthma is to have any meaning then it is crucial that subjects with non-specific cough are not included in this diagnostic category. Whereas all that wheezes probably coughs, all that coughs certainly does not wheeze.

SHEILA MCKENZIE

Queen Elizabeth Hospital for Children,

Hackney Road,

London E2 8PS

1 Warner J. Asthma: a follow up statement from an international paediatric asthma consensus group. Arch Dis Child 1992; 67: 240-8.

2 Jones A. Coughing, wheezing and the diagnosis of asthma. Practitioner 1990; 234: 274-6.

3 Burr ML. Diagnosing asthma by questionnaire in epidemiological surveys. Clin Exp Allergy 1992; 22: 509-10.

4 Anonymous. Cough and wheeze in asthma: are they interdependent? Lancet 1988; i: $447-8$.

5 Fuller RW, Jackson DM. Physiology and treatment of cough. Thorax 1990; 45: 425-30.

6 Higgenbottom T. Cough induced by changes of ionic composition of airway surface liquid. Bulletin of European Physiopathology and Respiration 1984; 20: 553-62.

7 Empey DW, Laitinen LA, Jacobs L, Gold WM. Mechanisms of bronchial hyperreactivity in normal subjects after upper respiratory tract infection. Am Rev Respir Dis 1976; 113: 131-9.

8 Choudry NB, Fuller RW, Pride NB. Sensitivity of the human cough reflex: effect of inflammatory mediators prostaglandin E2, bradykinin and histaeffect of inflammatory mediators prostaglandin
mine. Am Rev Respir Dis 1989; 140: 137-41.

9 Fujimura M, Sakamoto S, Kamio Y, Matsuda T. Cough receptor sensitivity and bronchial responsiveness in normal and asthmatic subjects. Eur Respir f 1992; 5: 291-5.

10 Pounsford JC, Birch MJ, Saunders KB. Effect of bronchodilators on the cough response to inhaled citric acid in normal and asthmatic subjects. Thorax 1985; 40: 662-7.

11 Fujimura M, Sakamoto S, Kamio Y, Matsuda T. Effects of methacholine induced bronchoconstriction and procaterol induced bronchodilation on cough receptor sensitivity to inhaled capsaicin and tartaric acid. Thorax 1992; 47: 441-5.

12 Fujimura M, Sakamoto S, Kamio Y, Bando T, Kurashima K, Matsuda T. Effect of inhaled procaterol on cough receptor sensitivity to capsaicin in Effect of inhaled procaterol on cough receptor sensitivity to capsaicin in patients with asthma

13 Young S, Bitsaku H, Caric D, McHardy GJR. Coughing can relieve or exacerbate symptoms in asthmatic patients. Respir Med 1991; 85: 7-12.

4 Chausow AM, Banner AS. Comparison of tussive effects of histamine and methacholine in humans. $\mathcal{F}$ Appl Physiol $1983 ; 55$ : 541-6.

15 Sheppard D, Rizk NW, Boushey HA, Bethel RA. Mechanism of cough and bronchoconstriction caused by distilled water. Am Rev Respir Dis 1983; 127: $691-4$.

16 Banner AS, Green J, O'Conner M. Relation of respiratory water loss to coughing after exercise. $N$ Engl $\mathcal{F}$ Med 1984; 311: 833-6.

17 Deal EC, McFadden ER, Ingram RH, Strauss RH, Jaeger J. Role of respiratory heat exchange in production of exercise-induced asthma. $\mathcal{J}$ respiratory heat exchange in pro

18 Galvez RA, McLaughlin FJ, Levison $\mathrm{H}$. The role of methacholine challenge in children with chronic cough. $\mathcal{F}$ Allergy Clin Immunol 1987; 79: 331-5.

19 Clifford RD, Radford M, Howell JB, Holgate ST. Prevalence of respiratory symptoms among 7 and 11 year old children and association with asthma. Arch Dis Child 1989; 64: 1118-25.

20 Clifford RD, Radford M, Howell JB, Holgate ST. Prevalence of atopy and range of bronchial response to methacholine in 7 and 11 year old schoolchildren. Arch Dis Child 1989; 64: 1126-32.

21 Clough JB, Williams JD, Holgate ST. Effect of atopy on the natural history of Sx, Pef, and BR in 7 and $8 \mathrm{y}$ old children with cough and wheeze. $\mathrm{Am}$ Rev Respir Dis 1991; 143: 755-60.

22 Sears MR, Jones DT, Holdaway MD, et al. Prevalence of bronchial reactivity to inhaled methacholine in NZ children. Thorax 1986; 41: 283-9.

23 Clough JB, Williams JD, Holgate ST. Profile of bronchial responsiveness in children with respiratory symptoms. Arch Dis Child 1992; 67: 574-9.

24 Anderson SD, Silverman M, Konig P, Godfrey S. Exercise-induced asthma. British fournal of Diseases of the Chest 1975; 69: 1-39.

25 Cloutier MM, Loughlin EM. Chronic cough in children: a manifestation of airway hyperactivity. Pediatrics $1981 ; 67: 6-12$.

26 Johnson D, Osborne LM. Cough variant asthma: a review of the clinical literature. ₹ Asthma 1991; 28: 85-90.

27 Ellul-Micallef $R$. Effect of terbutaline sulphate on chronic 'allergic' cough. $B M \mathcal{F} 1983$; 287: 940-3.

28 Korppi M, Laurikainen K, Pietikainen M, Silvasti $M$. Antitussives in the treatment of acute transient cough in children. Acta Paediatr Scand 1991; 80: $969-71$.

29 Thomson A, Pratt C, Simpson H. Nocturnal cough in asthma. Arch Dis Child 1987; 62: 1001-4.

30 Evald T, Munch EP, Kok-Jensen A. Chronic non-asthmatic cough is not affected by inhaled beclomethasone diproprionate. Allergy 1989; 44: 510-4

31 Boner AL, de Sefano G, Piacentini GL, et al. Perception of bronchoconstriction in chronic asthma. $\mathcal{F}$ Asthma 1992; 295: 323-30. 